\title{
FERTILIZATION OF RAT EGGS IN VITRO BY EPIDIDYMAL SPERMATOZOA AND THE DEVELOPMENT OF EGGS FOLLOWING TRANSFER
}

\author{
Y. TOYODA* AND M. C. CHANG \\ Worcester Foundation for Experimental Biology, \\ Shrewsbury, Massachusetts 01545, U.S.A.
}

(Received 12th December 1972)

\begin{abstract}
Summary. Newly ovulated eggs from immature rats treated with PMSG and HCG were 'inseminated' in vitro with spermatozoa recovered from the cauda epididymidis of mature males. A modified Krebs-Ringer bicarbonate solution, supplemented with glucose, sodium pyruvate, sodium lactate, bovine serum albumin and antibiotics, was used. Eggs and spermatozoa were incubated in $0.4 \mathrm{ml}$ medium under mineral oil at $37^{\circ} \mathrm{C}$ in a gas phase of $5 \% \mathrm{CO}_{2}$ in air.

Sperm penetration through the zona pellucida started 5 to $5 \frac{1}{2} \mathrm{hr}$ after insemination and the transformation of sperm head(s) into the male pronucleus occurred about $2 \mathrm{hr}$ later. Most of the penetrated eggs were at the two-cell stage 30 to $35 \mathrm{hr}$ after insemination. The percentage of eggs undergoing fertilization was $88.7 \%(316 / 356) 7$ to $20 \mathrm{hr}$ after insemination and that of fertilized eggs at 30 to $46 \mathrm{hr}$ after insemination was $75.3 \%(174 / 231)$. Only a few eggs cleaved to the four-cell stage after further incubation. A total of 203 two-celled eggs fertilized in vitro were transferred to the oviducts of fourteen pseudopregnant rats on the first day of dioestrus. Nine recipients became pregnant and forty-three fetuses and newborn young were obtained ( $21 \%$ of development).
\end{abstract}

\section{INTRODUCTION}

Since the publication of unequivocal evidence for fertilization of rabbit eggs in vitro (Chang, 1959), fertilization of mammalian eggs in vitro has been extended to the golden hamster (Yanagimachi \& Chang, 1963), mouse (Whittingham, 1968), rat (Toyoda \& Chang, 1968; Bregulla, 1969), cat (Hamner, Jennings \& Sojka, 1970), guinea-pig (Yanagimachi, 1972), pig (Harms \& Smidt, 1970) and human (Edwards, Bavister \& Steptoe, 1969). In a previous attempt to fertilize rat eggs in vitro, Toyoda \& Chang (1968) reported that epididymal spermatozoa, as well as spermatozoa recovered from the uterus, could penetrate the eggs when the zona pellucida was dissolved with proteolytic enzymes. Sperm penetration of intact eggs, however, was not observed. Recently, fertilization in vitro of intact rat eggs by capacitated spermatozoa recovered from the uterus of mated females has been reported by Miyamoto \& Chang

* Present address: Department of Animal Science, Kitasato University, Towada, Aomori 034, Japan. 
(1973a, b) but spermatozoa obtained from the cauda epididymidis of adult males were unable to penetrate the zona pellucida under their experimental conditions. As it has been shown in vivo that rat spermatozoa need capacitation before they can penetrate the eggs (Austin, 1951a; Noyes, 1953), the failure of epididymal spermatozoa to penetrate the zona in vitro would indicate that either the capacitation of spermatozoa did not occur or the eggs had lost their fertilizability before the spermatozoa were capacitated.

In view of the recent success in inducing in-vitro capacitation of epididymal spermatozoa of golden hamster (Yanagimachi \& Chang, 1964; Barros \& Austin, 1967; Yanagimachi, 1969), mouse (Iwamatsu \& Chang, 1970; Toyoda, Yokoyama \& Hosi, 1971; Pavlok \& McLaren, 1972; Mukherjee, 1972; Miyamoto \& Chang, 1972a, b) and guinea-pig (Yanagimachi, 1972), it was of interest to examine whether in-vitro capacitation of epididymal spermatozoa and fertilization of rat eggs could be achieved under similar conditions. It was also shown that these penetrated eggs could develop to the two-cell stage in the same medium and that they are capable of developing to near-term fetuses or newborn young when transferred to pseudopregnant recipients.

\section{MATERIALS AND METHODS}

\section{Preparation of medium}

The medium used in the present experiment was essentially the same as that used by Biggers, Whitten \& Whittingham (1971) and by Miyamoto \& Chang (1973a), except that the concentration of $\mathrm{NaCl}$ was $94.6 \mathrm{~mm}$ rather than $114 \cdot 2$ mM. It was a modified Krebs-Ringer bicarbonate solution containing 94.6 mм-NaCl, $4.78 \mathrm{~mm}-\mathrm{KCl}, 1.71 \mathrm{~mm}-\mathrm{CaCl}_{2}, 1.19 \mathrm{~mm}-\mathrm{KH}_{2} \mathrm{PO}_{4}, 1.19 \mathrm{~mm}-\mathrm{MgSO}_{4}$ and $25.07 \mathrm{~mm}-\mathrm{NaHCO}_{3}$, to which $21.58 \mathrm{~mm}$-sodium lactate, $0.5 \mathrm{~mm}$-sodium pyruvate, $5.56 \mathrm{~mm}$-glucose, $4 \mathrm{mg}$ crystalline bovine serum albumin $/ \mathrm{ml}, 50 \mu \mathrm{g}$ streptomycin sulphate $/ \mathrm{ml}$ and $75 \mu \mathrm{g}$ potassium penicillin $\mathrm{G} / \mathrm{ml}$ were added. The first five components were dissolved in one flask and stored in a refrigerator. Sodium bicarbonate $(0.154 \mathrm{M})$ was dissolved in a separate flask, gassed with $\mathrm{CO}_{2}$ for $15 \mathrm{~min}$, tightly stoppered and also stored at $4^{\circ} \mathrm{C}$. Phenol red $(2 \mathrm{mg} /$ litre) was added to these two solutions as a $\mathrm{pH}$ indicator. The other components, such as glucose, sodium lactate, sodium pyruvate, bovine serum albumin (crystallized and freeze-dried, Sigma Chemical Co.), and antibiotics were dissolved in a mixture of these solutions $(83.35 \mathrm{ml}$ first solution, $16.28 \mathrm{ml}$ second solution and $0.37 \mathrm{ml}$ sodium lactate) just before use. The final solution was sterilized through a filter sterilizer (Swinnex-13 Filter Unit, Millipore Co.) and $0.4 \mathrm{ml}$ (for fertilization) or $0.5 \mathrm{ml}$ (for sperm suspension) was placed in the centre of sterilized tissue culture dishes $(35 \times 10 \mathrm{~mm}$, Falcon Plastics) and immediately covered with warm paraffin oil (Soybolt, viscosity 125/135, Fisher Scientific Co.). The paraffin oil was previously autoclaved and equilibrated with $5 \% \mathrm{CO}_{2}$ in air in the presence of a small amount of medium and kept in a $\mathrm{CO}_{2}$ incubator.

\section{Preparation of sperm suspension}

Spermatozoa were obtained from the cauda epididymidis of mature CDstrain rats weighing more than $450 \mathrm{~g}$. A male was killed by cervical dislocation 
and its cauda epididymidis was removed aseptically. After cutting the epididymal ducts with a pair of sharp iridectomy scissors, one to three drops of the dense mass of spermatozoa were introduced to $0.5 \mathrm{ml}$ medium which had been kept in the $\mathrm{CO}_{2}$ incubator. Sperm suspensions showing vigorously progressive motility and usually containing 0.5 to $1.5 \times 10^{7}$ spermatozoa/ml were used. Some 5 to $10 \mathrm{~min}$ after the preparation, $0.04 \mathrm{ml}$ of the sperm suspension was introduced to $0.4 \mathrm{ml}$ of the fertilization medium under oil in a different dish by means of a calibrated Pasteur pipette, so that the final sperm concentration was about 0.4 to $1.4 \times 10^{6}$ spermatozoa $/ \mathrm{ml}$.

\section{Collection of eggs and 'insemination'}

Immature female rats of CD strain from 3 to 4 weeks old weighing 50 to $80 \mathrm{~g}$, were injected subcutaneously with 10 i.u. PMSG (Sigma Chemical Co.) 48 to $54 \mathrm{hr}$ before an intraperitoneal injection of 10 i.u. HCG (A.P.L., Ayerst Lab.) and killed $13 \frac{1}{2}$ to $17 \frac{1}{2} \mathrm{hr}$ after HCG injection. The oviducts were removed and the ampullar portion was put into a plastic dish containing warm mineral oil and the fertilization medium. The eggs in cumulus mass were dissected out of the oviducts and introduced into the fertilization medium about 15 to $60 \mathrm{~min}$ after the preparation of diluted sperm suspension. Great care was taken to avoid the contamination of blood and tissue exudate into the medium. The dishes were kept in a $\mathrm{CO}_{2}$ incubator $\left(5 \% \mathrm{CO}_{2}\right.$ in air) for 4 to $48 \mathrm{hr}$. In one experiment, the eggs at the two-cell stage were transferred to fresh medium after incubation for 34 to $35 \mathrm{hr}$, and were then incubated for a further 28 to $32 \mathrm{hr}$.

For the preincubation of epididymal spermatozoa, the sperm suspensions in concentrated form were kept in a $\mathrm{CO}_{2}$ incubator for $\frac{1}{2}$ to $1,2,4$ or $6 \mathrm{hr}$, after which $0.04 \mathrm{ml}$ of the suspension was placed in $0.4 \mathrm{ml}$ of the fertilization medium under oil and the eggs were examined 9 to $14 \mathrm{hr}$ after 'insemination'. For the study of various media and different volumes of medium, a similar procedure was employed.

\section{Examination of eggs}

At the end of incubation, eggs were picked up from the medium with a pipette, washed twice with the standard medium and placed in the centre of four vaseline spots on a glass slide. After being compressed gently with a cover-slip, the eggs were examined under a phase-contrast microscope for the assessment of fertilization. A small amount of $2.5 \%$ glutaraldehyde in phosphate buffer solution ( $\mathrm{pH} 7.4$ ) was first introduced to the slit between the cover-slip and the slide, and the slide was kept in cold $10 \%$ neutral formalin overnight for complete fixation. The prefixation of eggs with glutaraldehyde was found to be effective in preserving the zona pellucida. After fixation, the slides were rinsed with distilled water, dehydrated with $95 \%$ ethanol and stained with $0.25 \%$ lacmoid in $45 \%$ acetic acid for further examination.

The eggs were classified as 'penetrated eggs' if a spermatozoon was inside the perivitelline space or the eggs were undergoing fertilization. 'Eggs undergoing fertilization' denotes those eggs with enlarged sperm head(s) or with pronuclei. 'Fertilized eggs' denotes those cleaved eggs with fertilizing sperm tail(s) in the vitellus (Table 1). 


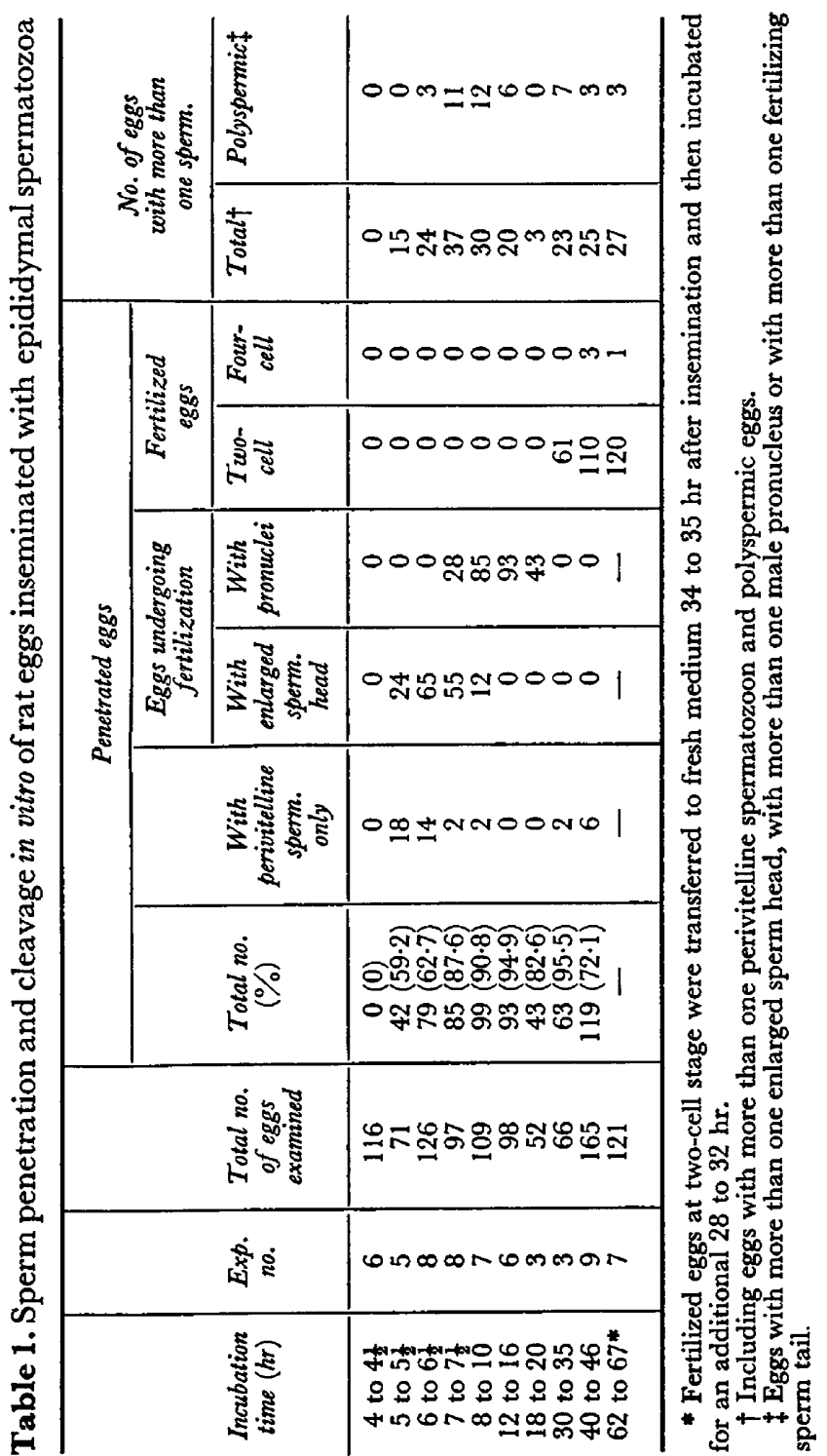


Transfer of fertilized eggs to pseudopregnant rats

The fertilized eggs at the two-cell stage, 34 to $35 \mathrm{hr}$ after insemination, were washed twice in the medium under paraffin oil and then transferred into the fimbriated end of the oviducts of pseudopregnant female rats, using a slight modification of the procedure of Noyes \& Dickmann (1961).

In order to induce pseudopregnancy, female rats of CD strain which had shown at least three consecutive regular 4-day oestrous cycles were stimulated by inserting a plastic rod connected to an electric vibrator into their vaginae. Stimulation was carried out between 08.00 and 09.00 hours on the morning of oestrus as assessed from the vaginal smear (Day 1). Between 11.00 and 13.00 hours on the following day (Day 2, the first day of dioestrus), the females were anaesthetized with an intraperitoneal injection of pentobarbital sodium (33 $\mathrm{mg} / \mathrm{kg}$ body weight), and the ovary and oviduct were exposed through a dorsal incision. A small cut was made at the antimesometrial site of the bursal membrane and the ovary was exposed from the bursa by means of small forceps. The fimbriated end of the oviduct was clearly recognized as an extrusion between the ovary and the oviduct. The eggs were picked up with a mouth-controlled pipette curved at the tip about $150 \mu \mathrm{m}$ in diameter ( Lin, 1968). The tip of the pipette was then inserted into the exposed fimbriated ostium and the contents were delivered by gentle pressure. About seven to eight eggs were transferred to each oviduct.

After transfer, the vaginal smear of these recipients was examined daily. They were killed if they showed pro-oestrous or oestrous smears and their uterine horns were examined for implantation sites. Pregnant females were either killed 19 days after transfer or allowed to litter. In the former group, the number of fetuses was counted and the individual fetus was weighed. The resorption sites were also recorded. In the latter group, the number of young born was counted on the day of parturition. The individual young were weighed at the age of 2 days and again 3 weeks later.

\section{RESULTS}

Sperm penetration and the cleavage of eggs

Table 1 presents the results when eggs were examined at various times after insemination. Sperm penetration through the zona pellucida was not observed at 4 to $4 \frac{1}{2} \mathrm{hr}$ after insemination but, at 5 to $5 \frac{1}{2} \mathrm{hr}$, about $60 \%$ of the eggs were found to have been penetrated. The percentage of penetrated eggs reached $88 \%$ at 7 to $7 \frac{1}{2} \mathrm{hr}$. The enlarged sperm head in the vitellus (Pl. 1, Fig. 1) was frequently observed at 5 to $6 \frac{1}{2} \mathrm{hr}$ and the male pronucleus appeared 7 to $7 \frac{1}{2} \mathrm{hr}$ after insemination. In all of the penetrated eggs examined 12 to $16 \mathrm{hr}$ after insemination, the sperm heads were found to have developed to male pronuclei (Pl. 1, Fig. 2). At the end of 18 to $20 \mathrm{hr}$ of incubation, eggs were still at the pronuclear stage (Pl. 1, Fig. 3) but both female and male pronuclei were located close together in the centre of the eggs.

Practically all the eggs examined 30 to $35 \mathrm{hr}$ after insemination were at the two-cell stage (Pl. 1, Fig. 4). It was assumed that these eggs had not cleaved parthenogenetically since a sperm tail was present in the vitellus (Pl. 1, Fig. 5). 
Among 165 eggs examined at 40 to $46 \mathrm{hr}$ after insemination, 110 eggs $(66.7 \%)$ were still at the two-cell stage and only three eggs were at the four-cell stage (P1. 1, Fig. 6). The low rate of fertilization in this group is due to the extremely low rate of sperm penetration in two of nine experiments. In the final group, 121 eggs at the two-cell stage were transferred into fresh medium and incubated for an additional 28 to $32 \mathrm{hr}$ (total incubation time: 62 to $67 \mathrm{hr}$ ). Only one egg cleaved to the four-cell stage and all the others remained at the two-cell stage. The nuclei of the blastomeres of these eggs were at the resting stage when examined.

Considerable proportions of the eggs were penetrated by more than one spermatozoon. The proportions of polyspermic penetration of the zona pellucida varied from 7.0 to $43.5 \%$ among groups incubated for various times, but did not show any increase with the lapse of incubation time. Polyspermic incorporation into the vitellus was less frequent $(0$ to $13 \%$ of all penetrated eggs). Of forty-five polyspermic eggs, forty were dispermic and five were trispermic.

In most penetrated eggs, good synchrony between the female and male components was observed during the process of fertilization, as was reported by Austin (1951b) for the penetrated eggs in vivo, but some of the penetrated eggs showed various degrees of abnormality at the second maturation division. In these eggs, the chromosomes were scattered in the cytoplasm at earlier stages and several small structures resembling pronuclei were found in later stages. Although the detailed examination of chromosomes was not performed in this experiment, it seemed that the scattering of chromosomes had started before the eggs were penetrated and this occurred more frequently in older eggs.

\section{Development of eggs fertilized in vitro following transfer}

A total of 203 two-cell eggs were transferred to fourteen rats proven to be pseudopregnant. Among these recipients, five showed oestrous vaginal smears 13 to 17 days after transfer and, at autopsy, only one implantation scar was observed. The remaining nine recipients had maintained their pregnancy to the end. Five of them were killed 19 days after transfer (Table 2) and the other four females were allowed to litter (Table 3).

\section{EXPLANATION OF PLATE 1}

Figs 1, 5 and 6 photographed after being stained; Figs 2, 3 and 4 photographed before fixation. All figs approx. $\times 250$.

Fig. 1. A rat egg examined $7 \mathrm{hr}$ after 'insemination', showing telophase of the second maturation division (arrow) and the enlarged sperm head (arrows).

Fic. 2. A rat egg examined $13 \frac{1}{2} \mathrm{hr}$ after insemination, showing one female and two male pronuclei together with two fertilizing sperm tails in the vitellus (arrows).

Fig. 3. A rat egg examined $18 \mathrm{hr}$ after insemination, showing two pronuclei and a fertilizing sperm tail (arrow).

FIg. 4. A fertilized rat egg at the two-cell stage, showing a nucleus in each blastomere 35 hr after insemination.

FIg. 5. A two-cell rat egg with two fertilizing sperm tails in the vitellus $42 \mathrm{hr}$ after insemination.

Frg. 6. A fertilized rat egg at the four-cell stage (the fertilizing sperm tail is not in focus) with a supplementary spermatozoon in the perivitelline space (arrow) $42 \mathrm{hr}$ after insemination. 
PLAIEI

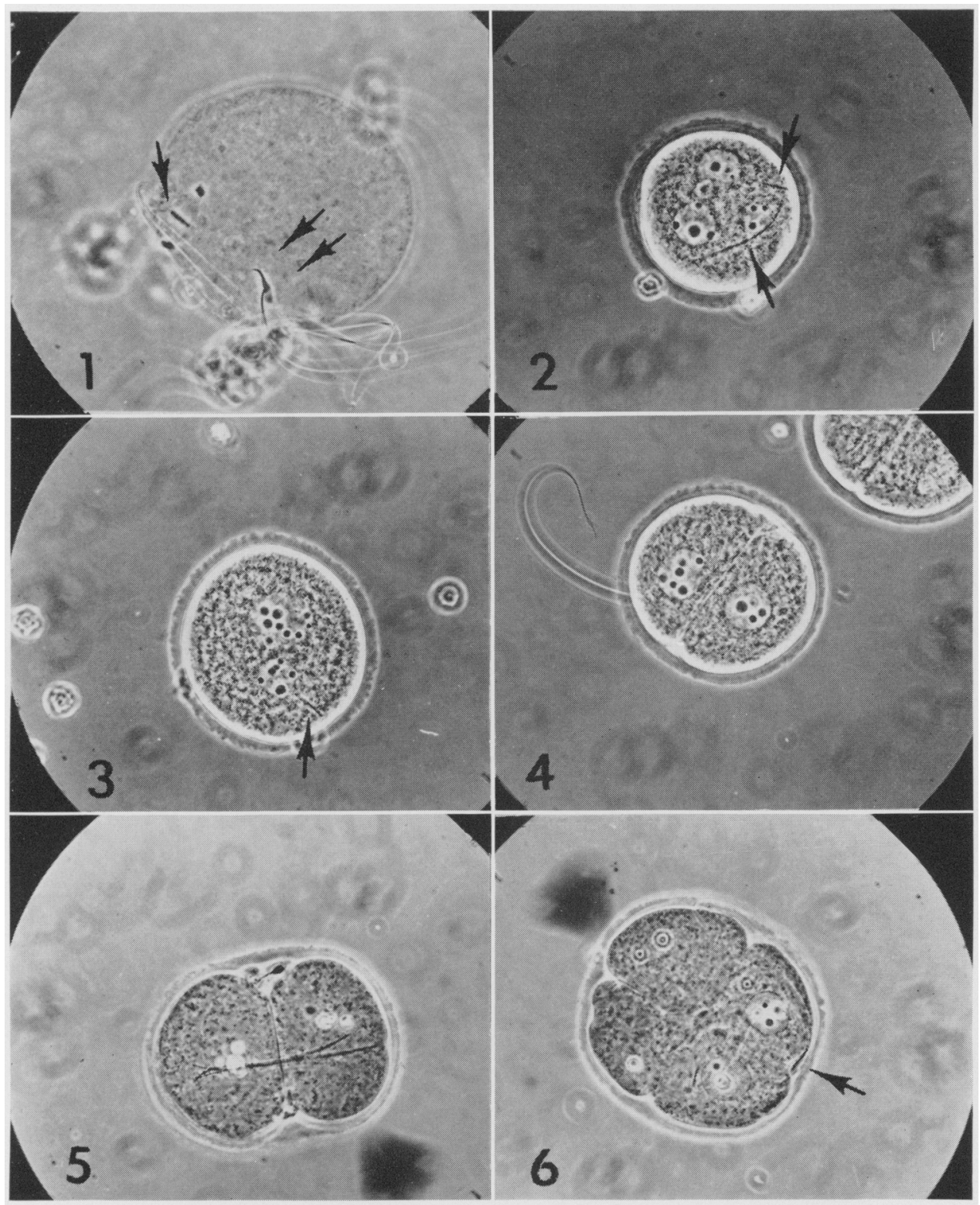

(Facing p. 14 
PLATE 2

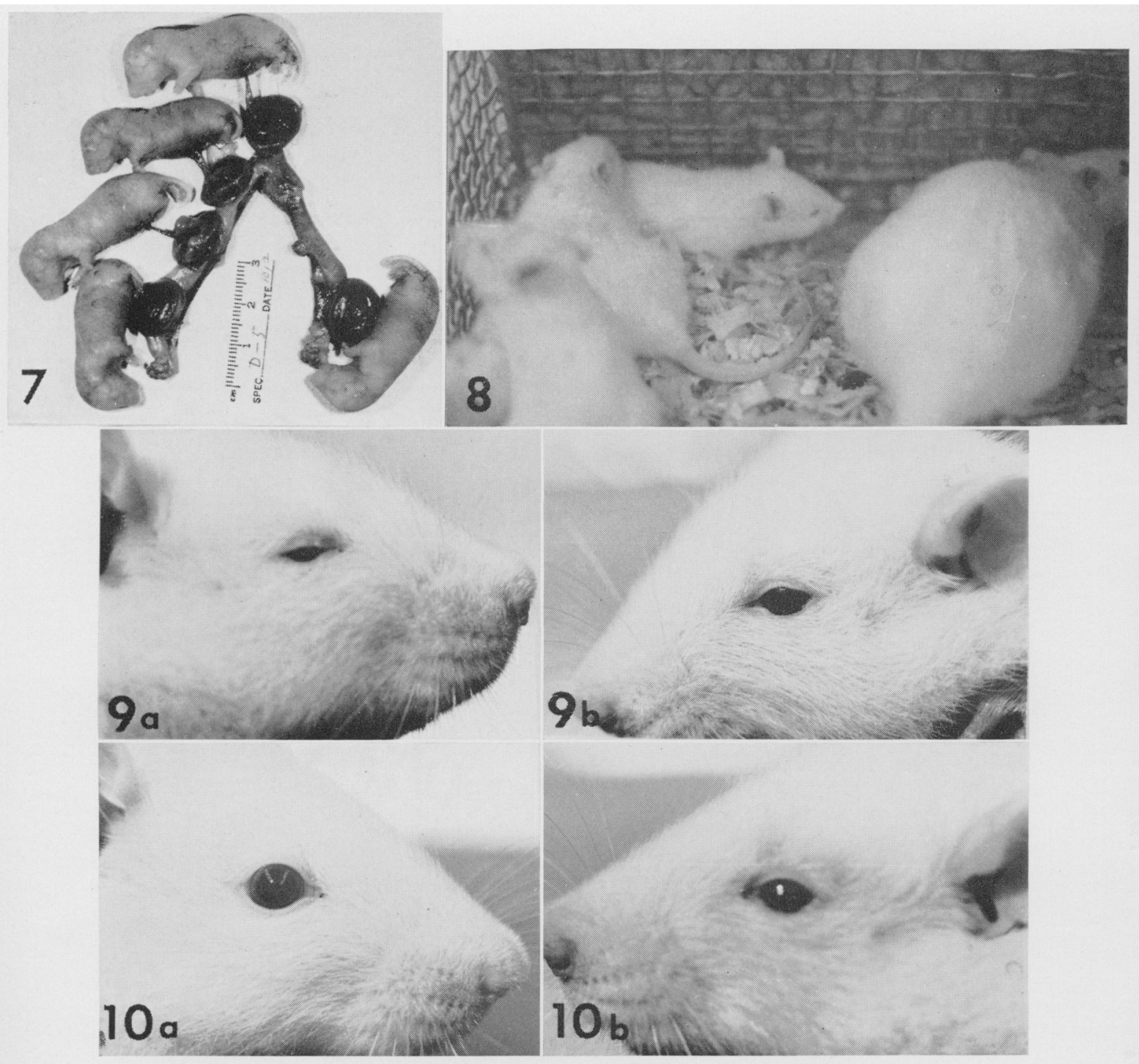

Fug. 7. Fetuses developed from two-cell rat eggs fertilized in vitro and transferred to a pseudopregnant recipient. The recipient was killed 19 days after transfer.

Fic. 8. Twenty-one-day-old young developed from eggs fertilized in vitro, with their recipient mother.

FIG. 9. The right and left eye of a 5-week-old rat developed from an egg fertilized in vitro, showing the variation of the size of eyes.

Fig. 10. The right and left eye of another 5-week-old rat, showing the normal size of the right eye and the smaller size of the left eye. 


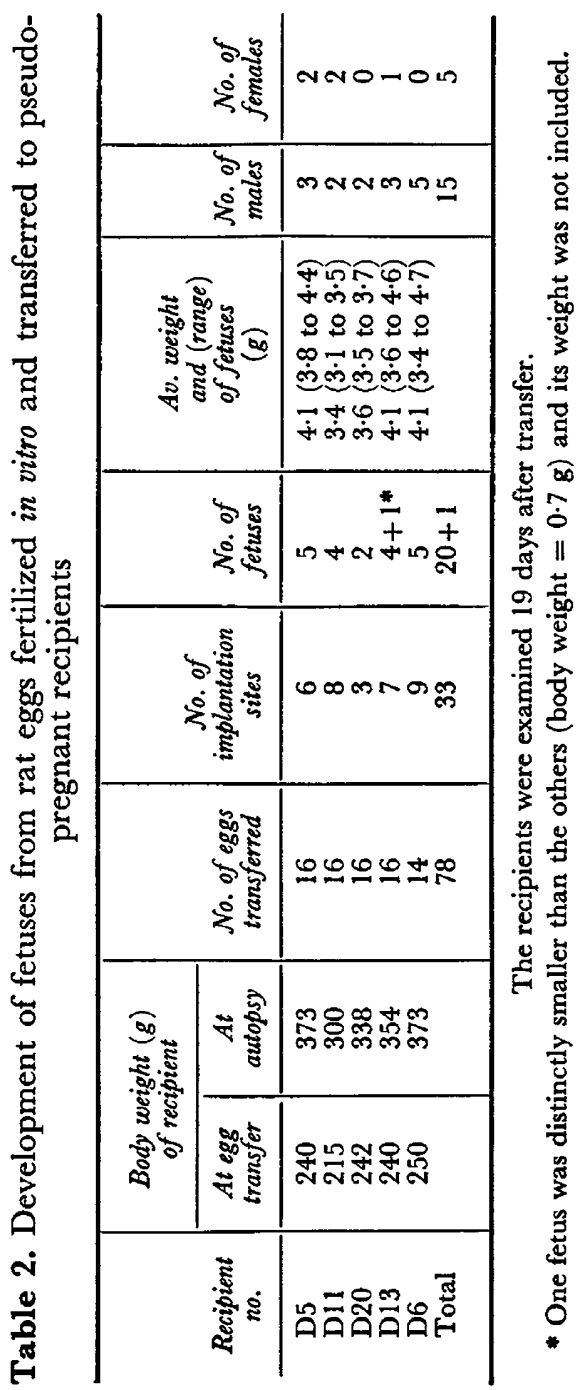




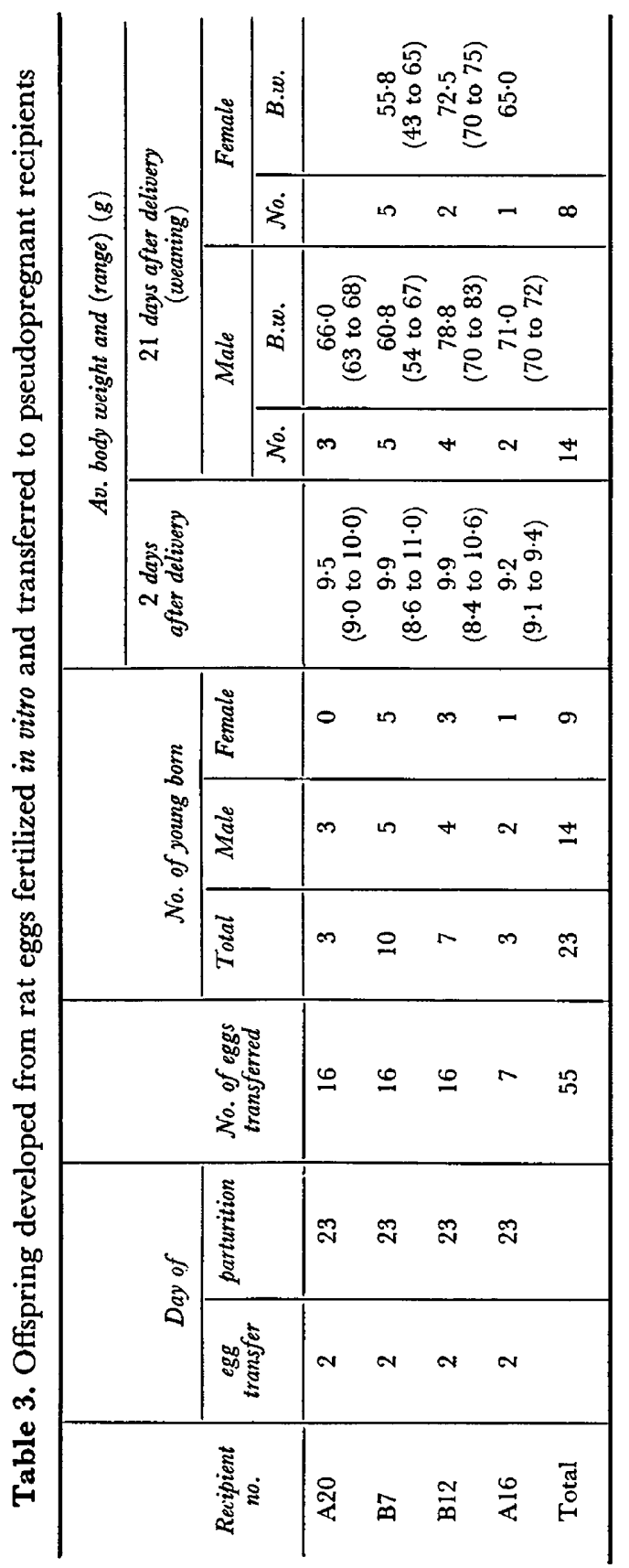


It can be seen from Table 2 that twenty $(25.6 \%)$ full-term fetuses developed from seventy-eight eggs transferred to five recipients. There was no gross abnormality among these fetuses (Pl. 2, Fig. 7). One fetus, which was exceptionally small (body weight $=0.7 \mathrm{~g}$ ), was present in a recipient and a total of thirteen resorption sites was found in their uterine horns. It is estimated from these observations that the preimplantation and postimplantation losses of embryos were 57.7 and $15.3 \%$, respectively. Of twenty full-term fetuses, fifteen were males and five were females. Although the case number is small, the deviation of sex ratio $(15: 5)$ was statistically significant $(P<0.05)$ according to $\chi^{2}$-test.

Twenty-three $(41.8 \%)$ normal young were born on Day 23 from four recipients which had received a total of fifty-five eggs (PI. 2, Fig. 8). The number of male young again slightly exceeded the number of female young $(14: 9)$, but this deviation was not significant. Summarizing all the data of the egg transfer experiment, it is calculated that forty-three $(21.1 \%)$ normal term fetuses and newborn young were obtained from 203 transferred eggs.

Only one female young was lost during the nursing period of 3 weeks; all the remaining infants have been successfully reared up to 6 weeks of age. Judging from their appearance, all of them have shown normal growth, except for a high incidence of microphthalmia. This condition was first noticed when the young were weaned at 3 weeks of age. Eleven $(50 \%)$ of twenty-two young $(1 / 3,8 / 10$, $2 / 6$ and $0 / 3$ for each litter) had abnormally small eyes at that time. Considerable variations were observed between individuals, and between left and right eyes in some cases (Pl. 2, Figs 9 and 10), from almost complete closure of eyelids to a slight reduction in the size of exposed eyeballs. During a subsequent observation period of 3 weeks, the abnormality has become less distinct in some young but the smaller size is still recognizable in some animals. No abnormality has so far been found among twenty-two young born from two recipients which had received twenty-six eggs, fertilized in vivo, at the two-cell stage from mated rats.

\section{Insemination with preincubated spermatozoa}

The motility of spermatozoa was very well maintained throughout the preincubation period for up to $6 \mathrm{hr}$ and samples with more than $70 \%$ of vigorously progressive spermatozoa were used for insemination. In spite of the well-maintained motility, the rate of penetrated eggs was decreased as the period of preincubation increased (Table 4). While spermatozoa preincubated

Table 4. Insemination of rat eggs in vitro with preincubated spermatozoa

\begin{tabular}{c|c|c|c|c|c}
\hline $\begin{array}{c}\text { Preincubation } \\
\text { time (hr) }\end{array}$ & $\begin{array}{c}\text { Exp. } \\
\text { no. }\end{array}$ & $\begin{array}{c}\text { No. of eggs } \\
\text { examined }\end{array}$ & $\begin{array}{c}\text { No. (\%) } \\
\text { of eggs } \\
\text { penetrated }\end{array}$ & $\begin{array}{c}\text { No. (\%) of } \\
\text { eggs undergoing } \\
\text { fertilization }\end{array}$ & $\begin{array}{c}\text { No. (\%) of } \\
\text { polyspermic eggs* }\end{array}$ \\
\hline$\frac{1}{2}$ to 1 & 6 & 110 & $98(89 \cdot 1)$ & $97(88 \cdot 2)$ & $32(29 \cdot 1)$ \\
2 & 4 & 84 & $62(73 \cdot 8)$ & $55(65 \cdot 4)$ & $11(13 \cdot 1)$ \\
4 & 7 & 141 & $14(9 \cdot 9)$ & $11(7 \cdot 8)$ & $5(3 \cdot 5)$ \\
6 & 6 & 132 & $\mathbf{8}(6 \cdot 0)$ & $7(5 \cdot 3)$ & $0(0)$ \\
\hline
\end{tabular}

The eggs were examined 7 to $10 \mathrm{hr}$ after insemination.

* Including a few eggs with more than one perivitelline spermatozoon. 
for less than $1 \mathrm{hr}$ penetrated ninety-eight of 110 eggs $(89.1 \%) 7$ to $11 \mathrm{hr}$ after insemination, the percentage of penetrated eggs was $73.8 \%(62 / 84)$ when inseminated with spermatozoa preincubated for $2 \mathrm{hr}$. A further significant drop of the penetration rate $(9.9 \%, 14 / 141)$ was observed when the preincubation time was extended to $4 \mathrm{hr}$. Spermatozoa preincubated for $6 \mathrm{hr}$ penetrated only eight $(6.0 \%)$ of 132 eggs.

Comparison of different media and the volume of media for fertilization in vitro

In order to find the causes of failure of fertilization of rat eggs in vitro in a previous experiment (Toyoda \& Chang, 1968), and in view of the successful fertilization of mouse eggs in vitro in a chemically defined medium (Toyoda $e t$ al., 1971), various media and different volumes of media for fertilization of rat eggs in vitro were examined. It can be seen from Table 5 that none of the media tested has given as high a rate of sperm penetration as the standard medium when the volume of medium was $0.4 \mathrm{ml}$. Substitution of sodium lactate with sodium chloride and the increase of sodium pyruvate to $1.0 \mathrm{~mm}$ in the standard medium resulted in sperm penetration of ten of thirty-eight eggs $(26.3 \%)$ as compared with fifty-two penetrated eggs from a total of fifty-eight eggs $(89.6 \%)$ in the standard medium containing sodium lactate. None of forty-three eggs were penetrated in Ham F10 supplemented with bovine serum albumin. Addition of $21.58 \mathrm{~mm}$-sodium lactate to Ham F10 resulted in only one penetrated egg among sixty-eight eggs examined.

Table 5. Comparison of different media and the volume of medium for fertilization of rat eggs in vitro

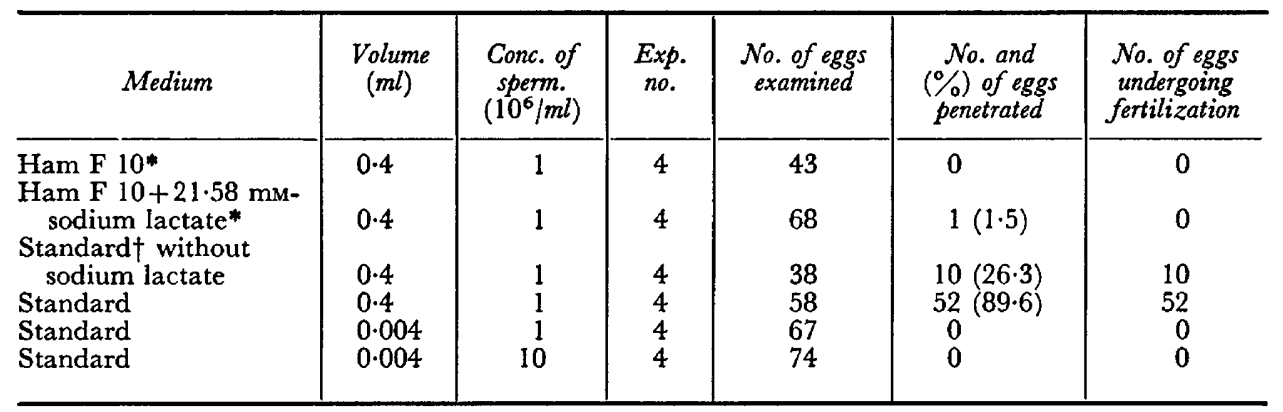

The eggs were examined 9 to $14 \mathrm{hr}$ after insemination.

* Supplemented with $4 \mathrm{mg}$ bovine serum albumin/ml and antibiotics.

$\dagger$ Containing 119.37 mM-NaCi and 1 mM-sodium pyruvate for the maintenance of osmotic pressure.

Furthermore, when the eggs and spermatozoa were incubated in a microdroplet (approximately $4 \mu \mathrm{l}$ ) of the standard medium according to the same procedure used in the previous study (Toyoda \& Chang, 1968), none of the 141 eggs from eight experiments were penetrated, whether the same concentration of spermatozoa was used or the concentration was increased ten times. In this microdroplet incubation, it was constantly observed that the motility of spermatozoa had decreased in a few hours in the presence of egg clot. Sperm motility was especially poor in the immediate vicinity of eggs observed under a dissecting microscope. 


\section{DISGUSSION}

The results obtained in the present experiment clearly demonstrated that the spermatozoa obtained from the cauda epididymidis of mature male rats were able to penetrate the egg in a chemically defined medium and such fertilized eggs could develop to normal young after transfer to pseudopregnant recipients. Although in-vitro fertilization of rat eggs with epididymal spermatozoa has been reported by Bregulla (1969), it is difficult to compare our results with those of Bregulla, because the descriptions of materials and methods in his study are so brief and his results are presented in the form of photographs.

Previous attempts (Toyoda \& Chang, 1968; Miyamoto \& Chang, 1973a, b) to achieve in-vitro fertilization of rat eggs with epididymal spermatozoa were unsuccessful. The medium Ham F10, one of the best supporting media for rat epididymal spermatozoa (Toyoda \& Chang, 1968), has been shown to be inadequate to permit sperm penetration because none of the eggs was penetrated in $0.4 \mathrm{ml}$ of this medium, even in the presence of bovine serum albumin (Table 5). This confirms the previous result. Addition of sodium lactate to Ham F10 was not effective (only one of sixty-eight eggs was penetrated) although omitting this component from the standard medium caused a significant reduction of the penetration rate $(26 \%$ versus $90 \%)$. Apparently, sodium lactate plays a rôle for fertilization in vitro but the composition of the medium as a whole is still of importance.

In our previous attempt (Toyoda \& Chang, 1968), eggs and spermatozoa were always incubated in a minute quantity of medium in order to minimize the dilution of cumulus component. During the present experiment, when a small amount of standard medium was used, complete failure to fertilize rat eggs in vitro was observed. When the volume of medium was increased approximately 100 times $(0.4 \mathrm{ml})$, a high proportion of eggs were penetrated $(90 \%$ versus $0 \%)$. The reason for such a favourable effect of 'dilution' is not clear at present, but it is conceivable that the essential components in a minute quantity of medium would have been used up in a short period and the metabolites would accumulate quickly, causing an unfavourable condition for fertilization. It has been reported, however, that sperm penetration of hamster (Yanagimachi \& Chang, 1964; Yanagimachi, 1969) and mouse (Iwamatsu \& Chang, 1970, 1971) eggs occurs efficiently in a microdroplet of medium under paraffin oil. The reported fertilization rates do, however, appear to be higher in a larger amount of medium (Toyoda et al., 1971; Miyamoto \& Chang, 1972a) than in a smaller amount (Iwamatsu \& Chang, 1970, 1971; Pavlok \& McLaren, 1972).

In the rabbit, Thibault \& Dauzier (1960) showed that the rate of fertilization was much increased after washing the eggs and postulated a fertilization-inhibiting factor, 'fertilizin', arising from freshly ovulated eggs. If this is true in the case of rodent eggs, the favourable effect of a large amount of medium would be the dilution of 'fertilizin'. Poor sperm motility in the immediate vicinity of the eggs observed in the microdroplet seems to support this view, but recent experiments on rabbit eggs (Bedford \& Chang, 1962; Brackett, 1969; Brackett, Killen \& Peace, 1971; Fraser, Dandeker \& Vaidya, 1971) do not support it. Repeated washing of mouse and hamster eggs before insemination has failed 
to show the presence of a fertilization-inhibiting factor in the cumulus (Iwamatsu \& Chang, 1970; Miyamoto \& Chang, 1972a). The sperm concentration and other factors may also play a rôle.

As shown in the present experiment, it takes about $5 \mathrm{hr}$ for the epididymal spermatozoa to penetrate the eggs. This fits the evidence obtained from studies in vivo which have shown that epididymal spermatozoa must undergo capacitation before they can penetrate the zona pellucida (Austin, 1951a; Noyes, 1953).

In order to define the nature of the environment required for the capacitation of spermatozoa, it is of importance to know whether preincubated spermatozoa can penetrate the eggs sooner. Although the time of sperm penetration was not determined accurately, the present experiment has shown that preincubation of rat spermatozoa for more than $4 \mathrm{hr}$ results in a marked decrease of their fertilizing ability, in spite of good maintenance of motility. By contrast, preincubation of hamster (Yanagimachi, 1969) and mouse (Iwamatsu \& Chang, 1970; Toyoda et al., 1971) epididymal spermatozoa resulted in a distinct shortening of the time of penetration. Recent studies of in-vitro fertilization of rat eggs by Miyamoto \& Chang (1973a, b) have shown that sperm penetration can occur when capacitated spermatozoa recovered from the uterus are inseminated but epididymal spermatozoa preincubated for 2 to $7 \mathrm{hr}$ were unable to penetrate the rat eggs. Loss of fertilizing ability during incubation may explain the failure.

The present experiment has shown that as with mouse eggs (Cross \& Brinster, 1970) a high proportion of penetrated rat eggs can develop to the two-cell stage 30 to $46 \mathrm{hr}$ after insemination without a change of medium (Table 1). Cleavage beyond the two-cell stage was not achieved even after the change of medium and subsequent culture for another 28 to $32 \mathrm{hr}$, although development of rat eggs from the eight-cell stage to the blastocyst stage has been reported by Folstad, Bennett \& Dorfman (1969).

The successful development of transferred eggs into fetuses has demonstrated that eggs which were fertilized in vitro are capable of development when transferred at the two-cell stage to pseudopregnant animals. This shows that other factors are required for second cleavage although earlier stages of fertilization can be maintained under our experimental conditions. In this connection, it is of interest to note that some special oviducal factor was thought to be necessary for mouse eggs to proceed from the two- to four-cell stage (Whittingham \& Biggers, 1967). It has since become apparent, however, that the one-cell pronuclear eggs are able to develop to the blastocyst stage in a chemically defined medium (Whitten \& Biggers, 1968). It is quite conceivable, therefore, that rat eggs fertilized in vitro may be able to cleave continuously if the culture medium can be improved.

In the present transfer experiment, the male rats, the egg donors and the recipients all belong to the same strain and are not genetically marked. It is unlikely, however, that some of the offspring are derived from the eggs of the recipients, since operations were performed on the recipients on the first day of dioestrus, about 32 to $36 \mathrm{hr}$ after ovulation when the fertilizability of their eggs had been lost (Blandau \& Jordan, 1941; Blandau, 1952), and the in-vitro fertilized eggs were washed twice and transferred 34 to $35 \mathrm{hr}$ after insemination when the fertilizing ability of spermatozoa had been completely lost, even if any 
spermatozoa were still attached to the eggs during transfer. We are confident that the fetuses and the young were derived from the transferred eggs and not from the eggs of the recipients.

By examination of the pregnant recipients before delivery, it appears that about $58 \%$ of the transferred eggs were lost before implantation, $15 \%$ were lost after implantation, and $27 \%$ were able to develop to fetuses, although the estimate of pre- and postimplantation loss of embryos may not be accurate, because laparotomy was not performed at the time of implantation. By counting the number of fetuses and newborn, it can be calculated that approximately $21 \%$ of the transferred eggs could develop to term. The rate of development is not considered to be low when compared with that of the rabbit (Chang, 1959; Thibault \& Dauzier, 1961; Bedford \& Chang, 1962; Brackett, 1969) and mouse (Whittingham, 1968; Mukherjee \& Cohen, 1970; Cross \& Brinster, 1970; Miyamoto \& Chang, 1972b; Mukherjee, 1972).

All the young, except one lost during the nursing period, have been quite healthy and have shown normal growth. It should be pointed out, however, that nearly half of the young obtained in the present experiment have shown some degree of microphthalmia. It is known that the size of the eyes is a quantitative character controlled by a polygenic system (Robinson, 1965) and that microphthalmia possesses both a genetic and a physiological basis (Hain, 1937). Since precise information of the incidence of such a defect is not known in the strain of rats used, it is not possible to decide whether the cause of the high incidence of microphthalmia in the present study is due to in-vitro fertilization of eggs or is due to other causes.

\section{ACKNOWLEDGMENTS}

This work was supported by grants (HD 03472 and GM 14370) from the U.S. Public Health Service and a grant from the Ford Foundation. One of us (M.G.G.) was a Research Career Awardee (K6-HD 18,334) of the National Institute of Child Health and Human Development. Thanks are due to the assistance of Mrs Rose Bartke.

\section{REFERENGES}

Austin, C. R. (1951a) Observations on the penetration of the sperm into the mammalian egg. Aust. $\mathcal{F}$. scient. Res. 4, 581 .

Ausrin, G. R. (1951b) The formation, growth, and conjugation of the pronuclei in the rat eggs. $\mathcal{H l} R$. microsc. Soc. 71, 295.

Barros, G. \& Austin, G. R. (1967) In vitro fertilization and sperm acrosome reaction in the hamster. 7. $\exp$. Zool. 166, 317 .

Bedford, J. M. \& GHANG, M. C. (1962) Fertilization of rabbit ova in vitro. Nature, Lond. 193, 898.

Biggers, J. D., Whitten, W. K. \& Whrrtingham, D. G. (1971) The culture of mouse embryos in vitro. In: Methods in Mammalian Embryology, p. 86. Ed. J. Daniel, Jr. Academic Press, New York.

BLANDAu, R. J. (1952) The female factor in fertility and sterility. I. Effects of delayed fertilization on the development of the pronuclei in the rat. Fert. Steril. 3, 349.

Blandau, R. J. \& Jordan, E. S. (1941) The effect of delayed fertilization on the development of the rat ovum. Am. F. Anat. 68, 275.

BracketT, B. G. (1969) Effects of washing the gametes on fertilization in vitro. Fert. Steril. 20, 127.

Brackett, B. G., Killen, D. E. \& Peace, M. D. (1971) Cleavage of rabbit ova inseminated in vitro after removal of follicular cells and zonae pellucidae. Fert. Steril. 22, 816.

Bregulla, K. (1969) In vitro-befruchtete tubare Rattenoocyten. Arch. Gynaek. 207, 568. 
Ghang, M. G. (1959) Fertilization of rabbit ova in vitro. Nature, Lond. 184, 466.

Gross, P. G. \& Brinster, R. L. (1970) In vitro development of mouse oocytes. Biol. Reprod. 3, 298.

Edwards, R. G., Bavister, B. D. \& Steptoe, P. C. (1969) Early stages of fertilization in vitro of human oocytes matured in vitro. Nature, Lond. 221, 632.

Folstad, L., Bennett, J. P. \& Dorfman, R. I. (1969) The in vitro culture of rat ova. F. Reprod. Fert. 18, 145.

Fraser, L. R., Dandekar, P. G. \& Vaidya, R. A. (1971) In vitro fertilization of tubal rabbit ova partially or totally denuded of follicular cells. Biol. Reprod. 4, 229.

Hain, A. M. (1937) Microphthalmia and other eye-defects throughout fourteen generations of albino rats. Proc. R. Soc. Edinb. 57, 66.

Hamner, G. E., Jennings, L. L. \& Sojka, N. J. (1970) Cat (Felis catus, L) spermatozoa require capacitation. F. Reprod. Fert. 23, 477.

HARMs, E. \& SMIDT, D. (1970) Untersuchungen zur in-vitro-Befruchtung follikularer und tubaler Eizellen von Schwein. Berl. Münch. tierärztl. Wschr. 83, 269.

Iwamatsu, T. \& Ghang, M. C. (1970) Further investigation of capacitation of sperm and fertilization of mouse eggs in vitro. F. exp. Zool. 175, 271.

Iwamatsu, T. \& Ghang, M. G. (1971) Factors involved in the fertilization of mouse eggs in vitro. $\mathcal{J}$. Reprod. Fert. 26, 197.

LiN, T. P. (1968) Survival of pronuclear mouse eggs kept at different temperatures. F. exp. Zool. 168, 501.

Miyamoto, H. \& Chang, M. C. (1972a) Fertilization in vitro of mouse and hamster eggs after the removal of follicular cells. F. Reprod. Fert. 30, 309.

Mryamoto, H. \& Ghang, M. G. (1972b) Development of mouse eggs fertilized in vitro by epididymal spermatozoa. F. Reprod. Fert. 30, 135.

Mryamoto, H. \& Ghang, M. G. (1973a) In vitro fertilization of rat eggs. Nature, Lond. 241, 50.

Miyamoto, H. \& Ghang, M. C. (1973b) Fertilization of rat eggs in vitro. Biol. Reprod. (In press).

Mukherjee, A. B. (1972) Normal progeny from fertilization in vitro of mouse oocytes matured in culture and spermatozoa capacitated in vitro. Nature, Lond. 237, 397.

Muknerjez, A. B. \& Cohen, M. M. (1970) Development of normal mice by in vitro fertilization. Nature, Lond. 228, 472.

Noyes, R. W. (1953) The fertilizing capacity of spermatozoa. West. F. Surg. Obstet. Gynec. 61, 342.

Noyes, R. W. \& Dickmann, Z. (1961) Survival of ova transferred into the oviduct of the rat. Fert. Steril. $12,67$.

Pavlok, A. \& Mclaren, A. (1972) The rôle of cumulus cells and the zona pellucida in fertilization of mouse eggs in vitro. F. Reprod. Fert. 29, 91.

Robinson, R. (1965) Genetics of the Norway rat. Pergamon Press, Oxford.

Thibault, G. \& Dauzier, L. (1960) Fertilisine et fécondation in vitro de l'œuf de la lapine. C.r. hebd. Seanc. Acad. Sci., Paris, 250, 1358.

Thibault, C. \& Dauzier, L. (1961) Analyse des conditions de la fécondation in vitro de l'œuf de la lapine. Annls Biol. anim. Biochim. Biophys. 1, 277.

Toyoda, Y. \& Ghang, M. G. (1968) Sperm penetration of rat eggs in vitro after dissolution of zona pellucida by chymotrypsin. Nature, Lond. 220, 589.

Toyoda, Y., Yoxoyama, M. \& Hosi, T. (1971) Studies on the fertilization of mouse eggs in vitro. Jap. J. Anim. Reprod. 16, 147.

Whitten, W. K. \& Biggers, J. D. (1968) Complete development in vitro of the preimplantation stages of the mouse in a simple chemically defined medium. F. Reprod. Fert. 17, 399.

Whittingham, D. G. (1968) Fertilization of mouse eggs in vitro. Nature, Lond. 220, 592.

Whitringham, D. G. \& BigGers, J. D. (1967) Fallopian tube and early cleavage in the mouse. Nature Lond. 213, 942.

YanAGimachi, R. (1969) In-vitro capacitation of hamster spermatozoa by follicular fluid. 7. Reprod. Fert. 18, 275.

Yanagimachi, R. (1972) Fertilization of guinea pig eggs in vitro. Anat. Rec. 174, 9.

Yanagmachi, R. \& GhanG, M. C. (1963) Fertilization of hamster eggs in vitro. Nature, Lond. 200, 281.

YaNAGimachi, R. \& Chang, M. C. (1964) In vitro fertilization of golden hamster ova. F. exp. Zool. 156, 361. 